\title{
Puccinia levis var. panici-sanguinalis em Brachiaria brizantha cv. Xaraés
}

\author{
Carlos Eduardo Marchi ${ }^{1,4}$, Celso Dornelas Fernandes ${ }^{1,2}$, Vanessa de Fátima Jerba ${ }^{1,4}$, Roberto Alexandre Ajul \\ Rezende ${ }^{3}$
}

${ }^{1}$ Embrapa Gado de Corte, Rod. 262, Km 4, Caixa Postal 154, CEP 79.002-970, fax: (67) 3368-2120, Campo Grande, MS; ${ }^{2}$ Professor colaborador da Uniderp, Caixa Postal 2153, CEP 79.003-010, Campo Grande, MS; ${ }^{3}$ Universidade Federal do Mato Grosso do Sul, CEP 79.804-970, Dourados, MS; ${ }^{4}$ Bolsista DCR (Fundect-CNPq).

Autor para correspondência: Carlos Eduardo Marchi, e-mail: cemarchi@cnpgc.embrapa.br Data de chegada: 28/12/2005. Aceito para publicação em: 20/07/2006.

Puccinia levis var. panici-sanguinalis é descrito como agente causal de ferrugem em gramíneas forrageiras. No Brasil, em campos da Embrapa Gado de Corte, o basidiomiceto foi constatado infectando braquiárias durante as avaliações do germoplasma importado da África, realizadas a partir de 1987. Os acessos de Brachiaria spp. avaliados diferiram quanto à suscetibilidade ao patógeno, sendo que B178 constituiu exemplo de B. brizantha que não apresentou sintomas de ferrugem. Após anos de estudos, perante o bom desempenho desse genótipo, o mesmo foi lançado comercialmente em 2002 como cultivar Xaraés.

Recentemente, observaram-se manchas cloróticas e necróticas, pústulas sub-epidérmicas irrompentes de coloração castanho-escura e seca prematura das folhas de 'Xaraés', típicos sintomas/sinais de ferrugem (Figura 1A-C). Esporos foram coletados das pústulas e observados ao microscópio de luz para a identificação do agente etiológico. Constatou-se a presença de teliósporos bicelulares com pedicelos longos inseridos na parede divisória das células ou lateralmente em uma destas (Figuras 1E-F), e urediniósporos unicelulares marrons escuros (Figura 1D). Em geral, os teliósporos apresentaram comprimento superior a $40 \mu \mathrm{m}$ e $3 \mu \mathrm{m}$ de espessura de parede lateral. Foram observados urediniósporos com 3 poros germinativos. Baseado nessas características morfológicas, a ferrugem foi identificada como $P$. levis var. panici-sanguinalis.

A constatação da interação $P$. levis var. panici-sanguinalis - $B$. brizantha cv. Xaraés demonstrou a capacidade desse patógeno em suplantar a resistência do hospedeiro. Visto que tal fenômeno pode ter ocorrido em outros genótipos de Brachiaria spp., avaliações serão conduzidas para verificar a reação de acessos anteriormente classificados como resistentes.

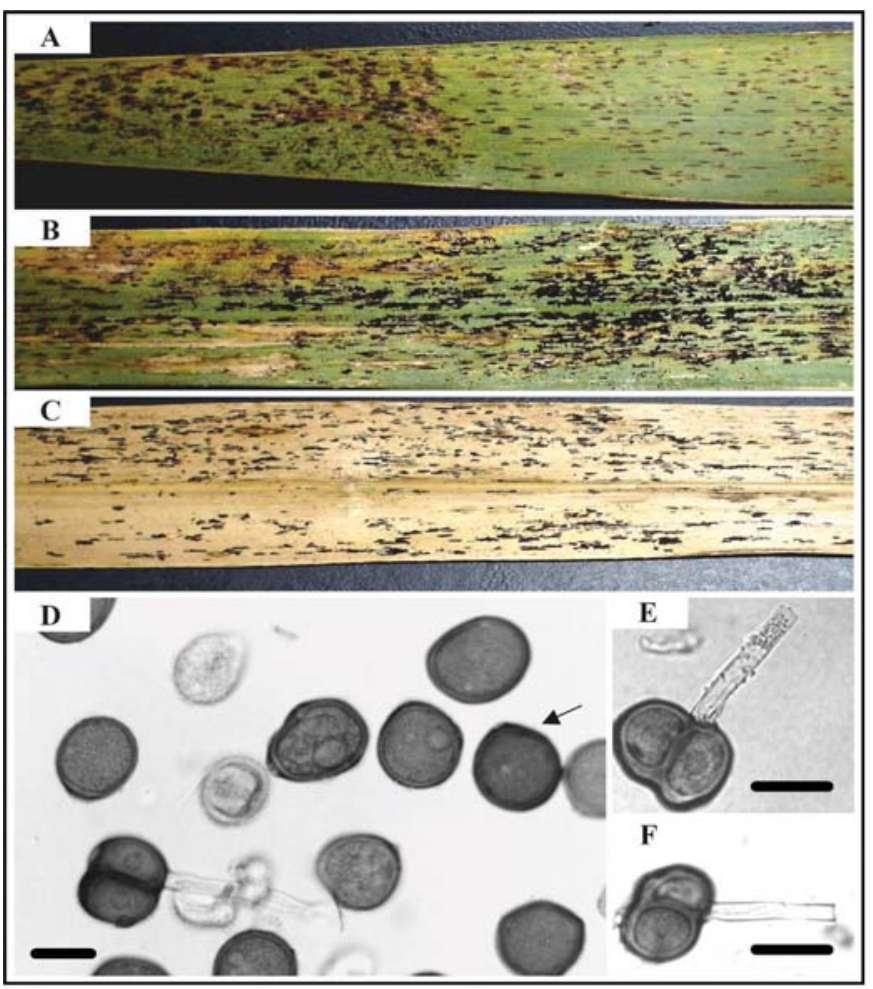

Figura 1. Puccinia levis var. panici-sanguinalis em Brachiaria brizantha cv. Xaraés. Pústulas nas faces adaxial (A) e abaxial (B) das folhas. Folha seca prematuramente (C). Urediniósporos (D) e teliósporos (E e F). Barras na parte inferior das fotos correspondem a $25 \mu \mathrm{m}$. 